\title{
Anti-cancer drugs-induced arterial injury: risk stratification, prevention, and treatment
}

\author{
Edit Gara ${ }^{1} \cdot$ Kristóf György Csikó $^{1} \cdot$ Zoltán Ruzsa $^{1} \cdot$ Gábor Földes $^{1} \cdot$ Béla Merkely $^{1}$
}

Received: 10 April 2019 / Accepted: 30 June 2019 / Published online: 10 July 2019

(c) The Author(s) 2019

\begin{abstract}
Vascular side effects of standard chemotherapeutic drugs and novel anti-tumor agents complicate treatment cycles, increase non-cancer-related mortality rates, and decrease the quality of life in cancer survivors. Arterial thromboembolic events (ATEE) are associated with most anti-cancer medications. Previous articles have reported a variety of vascular events including ST-segment elevation myocardial infarction as one of the most severe acute arterial attacks. Cardiologists should play an early role in identifying those at high risk for vascular complications and tailor anti-thrombotic therapies in keeping with thromboembolic and bleeding risks. Early preventive steps and individualized chemotherapy may decrease anti-tumor treatment-related vascular events. Here, we aim to provide an extensive review of anti-tumor drug-induced vascular injury (DIVI), pathomechanisms, and risk stratification underlining arterial events. We give a summary of clinical manifestations, treatment options, and possible preventive measures of DIVI. Additionally, the treatment of modifiable risk factors and tailored choice of chemotherapy must be considered in all oncology patients to prevent DIVI. We propose a complex tool for ATEE risk stratification which is warranted for early prediction leading to less frequent complications in cancer patients.
\end{abstract}

Keywords Drug-induced vascular injury · Anti-cancer treatment · Thromboembolic events · Prevention · Risk stratification

$\begin{array}{ll}\text { Abbreviations } \\ \text { ATEE } & \text { Arterial thromboembolic events } \\ \text { BEP } & \text { Bleomycin-etoposide-cisplatin } \\ \text { CAD } & \text { Coronary arterial diseases } \\ \text { DIVI } & \text { Drug-induced vascular injury } \\ \text { PAD } & \text { Peripheral arterial diseases } \\ \text { TKI } & \text { Tyrosine kinase inhibitors } \\ \text { vWF } & \text { von Willebrand factor }\end{array}$

Edit Gara

gara.editgara@gmail.com

Kristóf György Csikó

cs.georgex@gmail.com

Zoltán Ruzsa

zruzsa25@gmail.com

Gábor Földes

foldes.gabor@med.semmelweis-univ.hu

Béla Merkely

merkely.bela@gmail.com

1 Heart and Vascular Centre, Semmelweis University, 68 Városmajor str., Budapest 1122, Hungary

\section{Introduction}

Severe cardiovascular adverse events related to anti-tumor treatments have long been discussed including arterial thromboembolic events (ATEE), coronary and peripheral arterial diseases, secondary myocardial dysfunction, and arrhythmias [1]. Chemotherapy-related major adverse events may have long-term effects on quality of life, especially in early ages at the time of treatment. For instance, testicular cancer is the most frequent solid tumor in men aged $15-35$ years with an incident rate of 8/100,000-12/100,000 in developed countries [2]. Cisplatin, often used to treat testicular cancer, and other chemotherapeutic drugs also affect the vascular system and cause either acute (mainly thrombotic events) or chronic (e.g., arterial hypertension) arterial injury. A common regulatory or signaling pathway responsible for drug-induced vascular injury (DIVI) has not yet been discovered as each chemotherapeutic drug acts via different mechanisms. Treatment of DIVI, such as coronary interventions or hospitalization due to major adverse events, may interrupt or delay oncology therapy cycles. Additionally, cardiac function may be severely impaired if the side effects are recognized late in treatment (e.g., ischemic heart diseases) [3]. Therefore, oncology and cardiac specialists 
must cooperate so that mortality and survival rates of cancer patients can improve. Here, we aim to review and underpin the clinical importance of early risk stratification, prevention, and treatment of DIVI in arteries.

\section{Alkylating agents and platinum compounds}

Platinum-based treatments develop chemical bonds on cellular phospholipid membranes and cause direct cytotoxicity. ATEE are the most frequent vascular side effects (Table 1) induced via elevated coagulant state and direct endothelial toxic effects in response to alkylating agents [4]. During bleomycin-etoposide-cisplatin (BEP) treatment, levels of von Willebrand factor (vWF), intercellular adhesion molecule-1 (ICAM-1), plasminogen activator inhibitor-1 (PAI1), and tissue plasminogen activator (tPA), which are principal regulators of blood clotting, all increased [5]. Of note, peroxisome proliferator-activated receptor (PPAR) agonists such as rosiglitazone and troglitazone, and insulin sensitisers, were demonstrated to protect against cisplatin-induced DIVI [6, 7]. Moore et al. conducted a retrospective analysis, including 932 patients treated with cisplatin-based chemotherapy, and reported an $18.1 \%$ incidence rate of early DIVI which happened either during treatment or within 4 weeks after the last dose [6].

Half of these vascular events were presented as deep vein thrombosis (50\%), followed by pulmonary embolisms (25\%), or a combination of the two (13.6\%). About $2 \%$ of the patients developed arterial thrombosis, including cerebrovascular attack, and myocardial infarction. As well as causing early ATEE, endothelial dysfunction may lead to chronic vascular diseases. For instance, arterial hypertension usually occurs 10-20 years after cisplatin treatment [7]. Another study observed long-term incidences (2 years or more after diagnosis) of DIVI, and the authors reported that bleomycin-etoposide-cisplatin (BEP) has been associated with coronary artery diseases (CAD), a 4.3-fold higher risk in multivariate analysis, and with peripheral artery disease (PAD), a 4.1-fold higher risk in multivariate analysis [8]. Cyclophosphamides often damage pulmonary endothelial, mesothelial, and lymphatic endothelial cells and affect serous tissue of the pericardial sac, leading to pericarditis and pericardial effusion [9].

\section{Topoisomerase inhibitors}

Although anthracycline effects are fully characterized in the development of cardiomyopathy, their vascular side effects are not deeply understood. Anthracyclines cause late-onset and dose-dependent cardiomyopathy by overloading the reactive oxygen species (ROS), sarco/endoplasmic reticulum
(SERCA) dysfunction, and inactivation of cytoprotective pathways [10]. Furthermore, impaired endothelial-myocyte coupling was proposed as a possible mechanism of cardiotoxicity. Endothelial neuregulin-1 acts protectively and maintains endothelial-myocyte coupling, in vitro [11]. Direct DIVI and acute vascular events with anthracyclines are less frequently reported. An in vitro study emphasized that epirubicin treatment interferes with intracellular cAMP levels and lipid-peroxidation, and this results in endothelial injury [12]. Caspase-3-mediated apoptosis has also been observed in endothelial cells, in vitro. Small animal models have demonstrated microthrombus formation in coronary arterioles after doxorubicin treatment [13].

\section{Anti-microtubule agents}

Taxanes and vinca alkaloids target microtubules, suppress microtubule dynamics, and block proliferation through cell cycle arrest [14]. Furthermore, they induce tumor cell death by anti-angiogenic effects. Multiple cases have reported taxane-induced angina pectoris, myocardial ischemia, and myocardial infarction $[14,15]$. In these reports, vasospasm was suggested as a potential mechanism behind these ischemic events. Enhanced TNF- $\alpha$-induced tissue factor expression and downregulation of thrombomodulin were suggested as possible pathologic steps [11]. Other cardiovascular side effects of taxanes comprise sinus node dysfunction, bradycardia, and conduction abnormalities, mainly atrioventricular block [15]. Second-generation vinca alkaloid vinorelbine causes local toxicities (irritation, pain, phlebitis) in 30\% of patients [16]. Vascular injury develops due to increased ROS production and depleted glutathione levels. In vitro studies have addressed these mechanisms and showed the advantages of glutathione and $\mathrm{N}$-acetylcysteine substitution without clear clinical evidence of benefit [17].

\section{Anti-metabolites}

Pyrimidine analogues, mainly 5-fluorouracil (5-FU) and its oral form capecitabine, cause cardiac toxicity in $1-20 \%$ of patients. Most DIVI present as angina, hypotension, myocardial infarction, cardiogenic shock, and heart failure due to acute ischemic events [18]. A recent prospective study of 644 patients reported a low (1\%) incidence for both myocardial ischemia and infarction [19]; however, silent (asymptomatic) ischemia was reported in 5-6\% of the patients. Large-scale factors are responsible including coronary vasospasm, direct endothelial toxicity, increased oxidative stress, and altered rheology [20]. Gemcitabine causes peripheral ischemia and Raynaud's phenomenon in resistance arteries [21]. Furthermore, Takotsubo cardiomyopathy and microvascular 
Table 1 Suggested pathomechanisms and possible treatments of arterial DIVI

\begin{tabular}{|c|c|c|c|}
\hline Drug class & Pathomechanisms & Clinical manifestations & Prevention/treatment \\
\hline $\begin{array}{l}\text { Alkylating agents } \\
\text { Cyclophosphamide, Ifosfamide }\end{array}$ & $\begin{array}{l}\text { Direct endothelial toxic effect } \\
\text { DNA crosslinking } \\
\text { Decreased plasma VEGF }\end{array}$ & $\begin{array}{l}\text { Pulmonary arterial thrombosis } \\
\text { Pulmonary arterial hypertension } \\
\text { Serous pericarditis } \\
\text { Pulmonary fibrosis }\end{array}$ & Amifostine $^{b}$ \\
\hline $\begin{array}{l}\text { Platinum compounds } \\
\text { Cisplatin }\end{array}$ & $\begin{array}{l}\text { Direct endothelial damage } \\
\text { Increased ICAM-1 expression } \\
\text { Increased tPA and PAI-1 } \\
\text { Platelet activation } \\
\text { Elevated plasma levels of vWF, } \\
\text { FVIII } \\
\text { Increased PAI-1/tPA ratio } \\
\text { Increased production of pro-inflam- } \\
\text { matory endothelial micro particles } \\
\text { Enhancement of thrombin genera- } \\
\text { tion } \\
\text { Induced caspase } 3,7 \text { activity } \\
\text { Decreased NOS activity }\end{array}$ & $\begin{array}{l}\text { Increased intima-media thickness } \\
\text { Acute ischemic stroke } \\
\text { Acute myocardial infarction } \\
\text { Bilateral retinal ischemia } \\
\text { Lower limb digital necrosis } \\
\text { Raynaud's phenomenon } \\
\text { Abdominal aortic thrombosis } \\
\text { Celiac trunk thrombosis and splenic } \\
\text { infarction }\end{array}$ & $\begin{array}{l}\text { PPAR agonists: rosiglitazone } \\
\text { troglitazone } \\
\text { LMWH }^{\text {a }} \\
\text { ASA }^{\text {b }}\end{array}$ \\
\hline $\begin{array}{l}\text { Topoisomerase inhibitors } \\
\text { Anthracyclines: doxorubicin, } \\
\text { epirubicin }\end{array}$ & $\begin{array}{l}\text { DNA (TopIIb) damage } \\
\text { ROS generation } \\
\text { Decreased endothelium-mediated } \\
\text { relaxation } \\
\text { Induced caspase } 3,7 \text { activity, } \\
\text { apoptosis }\end{array}$ & $\begin{array}{l}\text { Angiopathy } \\
\text { Microvascular obstruction } \\
\text { Raynaud's phenomenon }\end{array}$ & $\begin{array}{l}\text { Zofenoprilat }^{\mathrm{a}} \\
\text { Dexrazoxane }^{\mathrm{c}}\end{array}$ \\
\hline $\begin{array}{l}\text { Anti-microtubule agents } \\
\text { Taxanes: docetaxel, paclitaxel }\end{array}$ & $\begin{array}{l}\text { Impaired of endothelial migration } \\
\text { and proliferation } \\
\text { Apoptosis induction } \\
\text { Downregulation of thrombomodulin } \\
\text { Increased TF expression } \\
\text { Impaired NO-mediated vasodilation }\end{array}$ & $\begin{array}{l}\text { Acute coronary syndrome } \\
\text { Vasoconstriction induced by } \\
\text { paclitaxel-eluting stents } \\
\text { Late stent thrombosis }\end{array}$ & Dual anti-platelet therapy ${ }^{\mathrm{c}}$ \\
\hline $\begin{array}{l}\text { Vinca alkaloids: vincristine, vin- } \\
\text { blastine, vinorelbine }\end{array}$ & $\begin{array}{l}\text { Inhibition of endothelial migration } \\
\text { and proliferation } \\
\text { Increased endothelial cell death } \\
\text { Increased ROS production }\end{array}$ & Microangiopathy & $N$-acetylcysteine ${ }^{\mathrm{b}}$ \\
\hline $\begin{array}{l}\text { Anti-metabolites } \\
\text { 5-fluorouracil, capecitabine, } \\
\text { methotrexate }\end{array}$ & $\begin{array}{l}\text { Direct endothelial damage } \\
\text { PKC-mediated vasoconstriction } \\
\text { ROS formation } \\
\text { Inhibition of VEGF-mediated } \\
\text { angiogenesis } \\
\text { Increased level of endothelin-1 } \\
\text { Apoptosis induction } \\
\text { Elevated homocysteine levels }\end{array}$ & $\begin{array}{l}\text { Angina } \\
\text { Arrhythmias } \\
\text { Myocardial ischemia Myocardial } \\
\text { infarction }\end{array}$ & $\begin{array}{l}\text { Probucol }^{\mathrm{b}} \\
\text { Dalteparin }^{\mathrm{b}} \\
\text { Nitro-glycerine }^{\mathrm{a}, \mathrm{b}, \mathrm{c}} \\
N \text {-acetylcysteine } \\
\text { Calcium channel blockers }^{\mathrm{c}} \\
\text { Folic acid }^{\mathrm{c}} \\
\text { Curcumin }^{\mathrm{a}}\end{array}$ \\
\hline $\begin{array}{l}\text { Targeted therapeutics } \\
\text { VEGF signaling pathway inhibi- } \\
\text { tors: bevacizumab (mAb) } \\
\text { sunitinib, sorafenib (TKIs) }\end{array}$ & $\begin{array}{l}\text { Impaired VEGF signaling (endothe- } \\
\text { lial survival) } \\
\text { Reduced NO production } \\
\text { Increased ET-1 release } \\
\text { Inhibition of PDGFR }\end{array}$ & $\begin{array}{l}\text { Hypertension } \\
\text { Myocardial ischemia and infarction } \\
\text { Cerebrovascular attack } \\
\text { Peripheral arterial ischemia } \\
\text { Hypertension } \\
\text { Takotsubo cardiomyopathy }\end{array}$ & $\begin{array}{l}\text { Anti-platelet drugs } \\
\text { LMWH }^{c} \\
\text { Low-dose acetylsalicylate }^{c}\end{array}$ \\
\hline $\begin{array}{l}\text { Anti-HER2: bevacizumab, trastu- } \\
\text { zumab } \\
\text { Anti-CD20 (rituximab) }\end{array}$ & Vasospasm & Arterial thrombosis & Anti-platelet drugs \\
\hline $\begin{array}{l}\text { BCR-ABL1 inhibitor TKIs: Nilo- } \\
\text { tinib, dasatinib, ponatinib }\end{array}$ & $\begin{array}{l}\text { Inhibition of TIE-2/TEK } \\
\text { Increased endothelial of ICAM-1, } \\
\text { VCAM- } 1, \text { E-selectin } \\
\text { Induction of casp- } 3 / 7 \text { mediated } \\
\text { apoptosis } \\
\text { Inhibition of PDGFR } \\
\text { Inhibition of VEGFR-2 } \\
\text { Vasoconstriction }\end{array}$ & $\begin{array}{l}\text { PAD } \\
\text { Acute coronary syndromes } \\
\text { Ischemic cerebrovascular events } \\
\text { Pulmonary arterial hypertension } \\
\text { Systemic arterial hypertension } \\
\text { Acute ischemic stroke }\end{array}$ & Anti-platelet drugs ${ }^{c}$ \\
\hline
\end{tabular}


Table 1 (continued)

\begin{tabular}{|c|c|c|c|}
\hline Drug class & Pathomechanisms & Clinical manifestations & Prevention/treatment \\
\hline $\begin{array}{l}\text { Hormonal therapies } \\
\text { Aromatase inhibitor, tamoxifen }\end{array}$ & $\begin{array}{l}\text { Endothelial damage } \\
\text { Hypercholesterolemia }\end{array}$ & $\begin{array}{l}\text { Myocardial infarction } \\
\text { Thrombotic vascular events }\end{array}$ & Anti-platelet drugs \\
\hline $\begin{array}{l}\text { Immunomodulatory drugs } \\
\text { Ipilimumab }\end{array}$ & $\begin{array}{l}\text { Vasoconstriction } \\
\text { Immune-mediated reaction }\end{array}$ & Angiopathy & $\begin{array}{l}\mathrm{LMWH}^{\mathrm{c}} \\
\text { Acetylsalicylate }^{\mathrm{c}}\end{array}$ \\
\hline $\begin{array}{l}\text { Antibiotics with anti-cancer effect } \\
\text { bleomycin }\end{array}$ & $\begin{array}{l}\text { FAS ligand upregulation } \\
\text { Increased production of ROS: } \\
\text { bleomycin-Fe(II) } \\
\text { NOS inhibition } \\
\text { Increased ICAM-1 expression } \\
\text { Increased amounts of tPA and } \\
\text { PAI-1 }\end{array}$ & $\begin{array}{l}\text { Limb ischemia } \\
\text { Raynaud's phenomenon }\end{array}$ & $\begin{array}{l}\text { PPAR agonists: rosiglitazone } \\
\text { troglitazone }\end{array}$ \\
\hline
\end{tabular}

ASA acetylsalicylate, DNA deoxyribonucleic acid, ET-1 endothelin-1, FVIII factor VIII, ICAM-1 intercellular adhesion molecule-1, LMWH lowmolecular-weight heparin, $N O$ nitric oxide, $N O S$ nitric oxide synthase, $P A D$ peripheral artery disease, PAI-1 plasminogen activator inhibitor-1, $P D G F R$ platelet-derived growth factor receptor, $P K C$ protein kinase $\mathrm{C}, P P A R$ peroxisome proliferator-activated receptors, $R O S$ reactive oxygen species, $T F$ tissue factor, $T I E-2, T E K$ angiopoietin-1 receptor, $t P A$ tissue plasminogen activator, $V C A M$ vascular cell adhesion molecule-1, $V E G F$ vascular endothelial growth factor, VEGFR-2 vascular endothelial growth factor receptor-2, $v W F$ von Willebrand Factor

${ }^{\mathrm{a}}$ In vitro preclinical

${ }^{\mathrm{b}}$ In vivo preclinical

${ }^{\mathrm{c}}$ In guidelines

angiopathy were associated with capecitabine administration [22]. The anti-folate drug methotrexate (MTX) is known to cause vascular and endothelial injury [23]. During MTX treatment, the availability of tetrahydrofolate reductase leads to hyperhomocysteinemia, a risk factor for vascular events [23]. Concomitant folic acid (leucovorin) supplementation normalizes plasma homocysteine levels during MTX treatment [23].

\section{Targeted therapeutics}

Monoclonal antibodies may cause systemic side effects by significant cytokine release upon administration [24]. These range from mild erythema to severe bronchospasm and anaphylactic shock [25]. VEGF signaling pathway inhibitors have an increased risk for arterial thrombosis as they decrease endothelial cell survival and proliferation [1, 26]. The anti-VEGF-A monoclonal antibody bevacizumab, trastuzumab, and tyrosine kinase inhibitor (TKI) sorafenib cause vasospasm and arterial thrombosis in $2.6 \%$ and $1.4 \%$ of patients, respectively [27, 28]. Clinically, the ATEE presented as myocardial infarction or cerebral ischemic attacks $[27,28]$. A decrease in nitric oxide (NO) synthase activity, inhibition of the PDGF receptor, and consequent rarefaction of pericytes are suggested to be involved in sorafenib toxicity $[11,28]$. Of note, a group of anti-VEGFR-TKIs: sunitinib, sorafenib, pazopanib, and vandetanib were shown not to increase the risk of DIVI [29].

Hypertension is a common side effect of VEGF-inhibitors with an incidence above $20 \%$. Hypertensive response can occur from initiation (within hours) until 1 year after treatment [29]. Proposed mechanisms include NO pathway inhibition, reduced microvascular capacity and flow, oxidative stress, and glomerular injury [28, 29]. BCR-ABL1 TKIs have unique vascular safety profiles, which differ from other TKIs. The first-generation BCR-ABL1 inhibitor, imatinib, has been described as a safe drug regarding cardiovascular toxicities. The second-generation drug dasatinib is primarily associated with pulmonary arterial hypertension, and nilotinib is associated with increased risk of peripheral arterial disease, myocardial and cerebrovascular ischemia, and metabolic changes (hyperglycemia and dyslipidemia). The third-generation drug ponatinib is associated with hypertension, and ATEE [29]. Endothelial damage leading to pro-atherogenic and anti-angiogenic effects are the suggested pathomechanisms [27-29] (Table 1).

\section{Hormonal therapies}

Aromatase inhibitors and tamoxifen are used in post-menopausal hormone receptor-positive breast cancer treatment. The use of aromatase inhibitors has increased the relative risk of myocardial infarction and other vascular side effects compared to tamoxifen [30, 31]. Aromatase inhibitor therapy has also been associated with increased prevalence of hypercholesterolemia and hypertension [31, 32]. Tamoxifen has been associated with a higher risk of ATEE compared to aromatase inhibitors [31]. 


\section{Immune checkpoint inhibitors}

Monoclonal antibodies target immune checkpoints to facilitate natural killer T cells and other innate immunityrelated anti-tumor responses. These checkpoint inhibitors may lead to severe vascular side effects which mainly comprise inflammatory responses, mesothelial, and lymphatic endothelial injury: vasculitis, pericarditis, and myocarditis [33]. Ipilimumab is a CTLA-4 inhibitor which targets cytotoxic T cells. Side effects, such as diffuse rash and itching, can relate to microangiopathy [34]. Thalidomide and lenalidomide are immunomodulatory agents that reduce the level of TNF- $\alpha$ and consequently have anti-angiogenic activity and also inhibit leukocyte migration. They are used in the treatment of myeloma multiplex [35]. The anti-tumor anti-biotic bleomycin is known to cause limb ischemia and Raynaud's phenomenon after the administration of the first dose $[36,37]$.

\section{Risk assessment}

The European Society of Cardiology (ESC) published a consensus paper to evaluate the cardiovascular risk of patients receiving anti-tumor treatment [38]. The ESC position paper is comprised of a cardiovascular risk assessment, which is recommended by the American Society of Clinical Oncology (ASCO), the Canadian Cardiovascular Society, and the European Society of Medical Oncology (ESMO) [39, 40].
However, the Khorana score is a recommended tool to evaluate the risk of venous thrombosis, no risk score is designed to assess the risk of ATEE [41]. Limitations of the Khorana score include the presence of platinum and pyrimidine analogue therapy, where risk stratification was not sensitive enough in the early stages of tumors. Therefore, the initiative of a "vascular fingerprint," a risk calculation score, has been suggested to detect risk of adverse arterial events among patients with anti-tumor therapy (Table 2) [10, 12, 42]. Cisplatin treatment, type and stage of primary malignancy, age, presence of cardiovascular diseases, elevated LDH, retroperitoneal metastatic lymph nodes in germ cell tumors, and high Khorana score, but not pre-chemotherapy platelet number and BMI, are independent risk factors for DIVI [8].

\section{Prevention and treatment}

In accordance with the latest ASCO guidelines, the ESC does not recommend routine prophylactic treatment for preventing ATEE among cancer patients [38, 39]. Lowmolecular-weight heparin (LMWH) prophylaxis may be proposed individually for high-risk patients (Khorana Score $\geq 3$ ). However, Moore et al. suggest that all patients treated with cisplatin, including patients with a low Khorana score, should receive prophylaxis, if bleeding risk is not elevated [6]. In a retrospective study involving germ cell tumor, patients treated with only cisplatin, prophylactic LMWH treatment, halved the number of venous DIVI [43]. The greatest reduction of ATEE by nadroparin versus

Table 2 Complex risk stratification for arterial thromboembolic events [10, 12, 42]

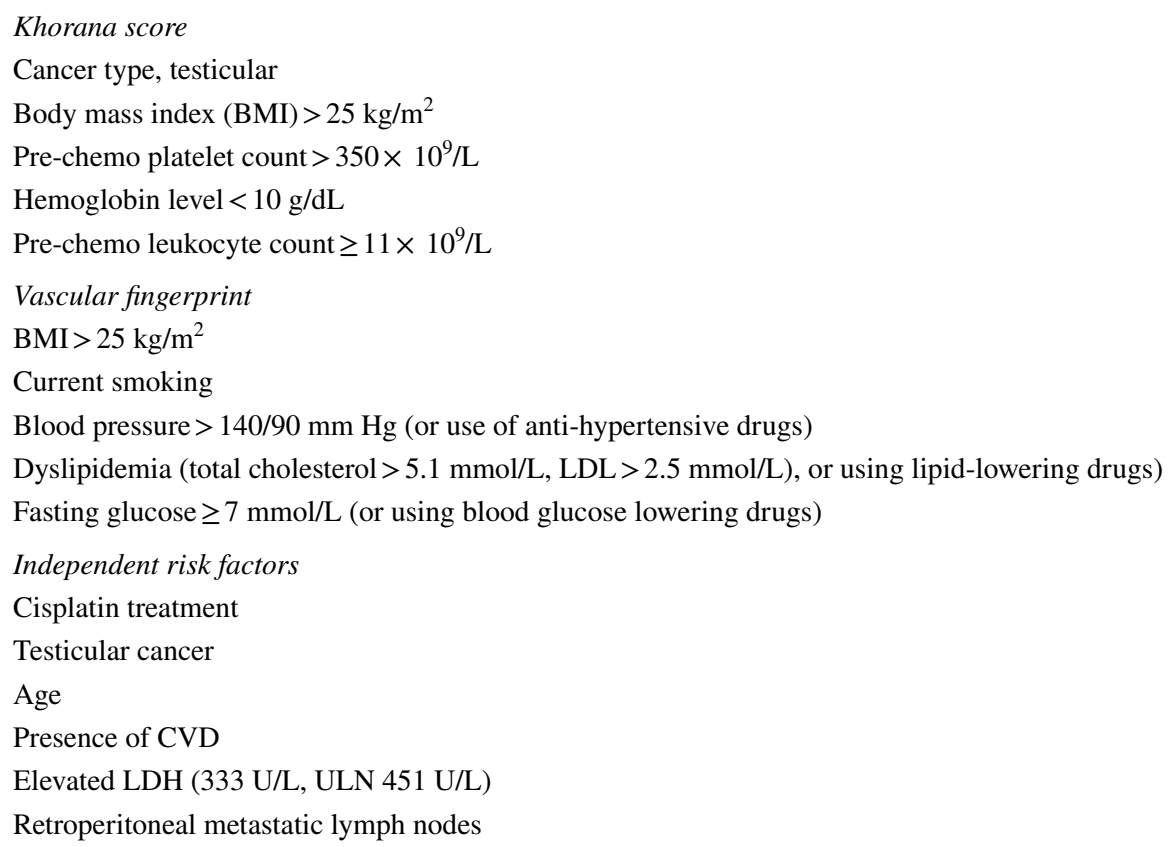


placebo was shown in patients receiving either cisplatin, carboplatin, or gemcitabine alone or in combination [44-46]. Multiple myeloma patients receiving thalidomide or lenalidomide combined with chemotherapy or dexamethasone should be treated with low-dose acetylsalicylate (low risk) or LMWH (high risk) [35]. According to the findings of the PROTECHT trial, nadroparin reduced the incidence of DIVI by nearly $50 \%$ among patients with advanced oncological diseases [47]. Clinical trials are underway to investigate different preventive strategies. Factor Xa inhibitor apixaban vs placebo (NCT02048865), low-dose acetylsalicylate vs simvastatin vs placebo (NCT02285738), and enoxaparin vs acetylsalicylate (NCT01763606) are being evaluated.

The use of nitrates and/or calcium channel inhibitors can be considered as a possible regular treatment in the instance of coronary vasospasm (ECG changes or angiography). Close follow-up and anti-platelet drugs should be considered in asymptomatic PAD cancer patients. In the case of severe PAD at baseline or during cancer therapy, revascularization strategy should be evaluated and discussed by a multidisciplinary team. ACE inhibitors and beta-receptor blockers should also be administered to prevent or reverse myocardial and vascular remodeling [38].

Given the short of clinical evidence in prevention and treatment of ATEE, large registries are urgently needed to better understand vascular side effects and therapies with mortality benefit. Additionally, extensive in vitro studies are warranted to model pathomechanisms of arterial DIVI, such as altered regulation of vascular tone, disturbances in endothelial inflammatory responses, barrier function, and hemostasis.

\section{Conclusion and outlook}

Mortality rates of cancer patients have had noticeable decreases due to the latest anti-tumor drugs and innovative surgical techniques. In parallel, the number of treatmentrelated side effects is increasing. Various studies and case reports have been focusing on cardiovascular toxicities induced by cisplatin and other chemotherapeutic drugs. The risk of incident myocardial infarction was significantly increased after cisplatin-based treatment, hazard ratio 3.1 vs control group [48]. Significantly, a large study involving 15,006 patients with testicular non-seminoma cancer quantified the short-term risk of death due to DIVI. Surprisingly, a 4.8-fold increased risk of death was reported within 1 year of chemotherapy (mostly BEP) compared to the control group (non-seminoma patients treated with surgery only) [45, 49]. Chemotherapeutic drugs have diverse mechanisms of action and extensive clinical presentations of major vascular adverse events.
Clinical scenarios are frequently complicated by radiation-induced side effects which mainly occur during longterm follow-up [50]. Radiation itself rarely causes ATEE, but rather generates increased arterial stiffness, hypertension, and fibrosis of myocardial and connective tissues. Considering the high number of ATEE among cancer patients, more sensitive and earlier risk stratification tools are warranted. We suggest developing and implementing a combined score including the Grace Score, Khorana score, and vascular fingertip score.

To put this into clinical practice, once the combined risk for ATEE exceeds the risk of bleeding, low-dose anti-coagulation would be recommended, preferably with unfractionated heparin. This can be safely tailored if patient condition deteriorates, bleeding develops, or surgery proceeds. Prophylaxis may be administered during all chemo-cycles and 5-10 days post-chemo. The risk stratification strategy, followed by an aggressive treatment of modifiable risk factors, should be introduced in conjunction with planning oncology treatment. Treatment of modifiable risk factors comprises quitting smoking, healthy diet, lipid lowering, blood pressure-lowering, and anti-diabetic medications. Despite the vast amount of research and clinical focus, there is still an urgent need to develop specific guidelines on the prevention and management of ATEE. Specifically, individual and sensitive risk stratification is warranted. Guidelines may include the localized site of primary tumor and drug-specific recommendations to predict risk and prevent ATEE.

Acknowledgements Open access funding provided by Semmelweis University (SE).

Author contributions EG and GC drafted the manuscript and tables. GF, ZR, and BM critically revised the manuscript. All authors approved the final manuscript.

Funding This study was funded by National Research, Development and Innovation Office of Hungary (Grant Number: NKFIA; NVKP-161-2016-0017, Higher Education Institutional Excellence Program of the Ministry of Human Capacities in Hungary, within the framework of the Therapeutic Development thematic program of the Semmelweis University).

\section{Compliance with ethical standards}

Conflict of interest The authors declare that they have no conflict of interest.

Open Access This article is distributed under the terms of the Creative Commons Attribution 4.0 International License (http://creativeco mmons.org/licenses/by/4.0/), which permits unrestricted use, distribution, and reproduction in any medium, provided you give appropriate credit to the original author(s) and the source, provide a link to the Creative Commons license, and indicate if changes were made. 


\section{References}

1. Cameron AC, Touyz RM, Lang NN. Vascular complications of cancer chemotherapy. Can J Cardiol. 2016;32:852-62.

2. Hayes-Lattin B, Nichols CR. Testicular cancer: a prototypic tumor of young adults. Semin Oncol. 2009;36:432-8.

3. Bellinger AM, Arteaga CL, Force T, Humphreys BD, Demetri GD, Druker BJ, et al. Cardio-oncology. Circulation. 2015;132:2248-58.

4. Dieckmann KP, Struss WJ, Budde U. Evidence for acute vascular toxicity of cisplatin-based chemotherapy in patients with germ cell tumour. Anticancer Res. 2011;31:4501-5.

5. Dieckmann K-P, Gerl A, Witt J, Hartmann J-T. Myocardial infarction and other major vascular events during chemotherapy for testicular cancer. Ann Oncol. 2010;21:1607-11.

6. Moore RA, Adel N, Riedel E, Bhutani M, Feldman DR, Tabbara $\mathrm{NE}$, et al. High incidence of thromboembolic events in patients treated with cisplatin-based chemotherapy: a large retrospective analysis. J Clin Oncol. 2011;29:3466-73.

7. de Haas EC, Altena R, Boezen HM, Zwart N, Smit AJ, Bakker SJL, et al. Early development of the metabolic syndrome after chemotherapy for testicular cancer. Ann Oncol. 2013;24:749-55.

8. Haugnes HS, Wethal T, Aass N, Dahl O, Klepp O, Langberg $\mathrm{CW}$, et al. Cardiovascular risk factors and morbidity in longterm survivors of testicular cancer: a 20 -year follow-up study. J Clin Oncol. 2010;28:4649-57.

9. Kachel DL, Martin WJ. Cyclophosphamide-induced lung toxicity: mechanism of endothelial cell injury. J Pharmacol Exp Ther. 1994;268:42-6.

10. Renu K, Abilash VG, Tirupathi TP, Arunachalam S. Molecular mechanism of doxorubicin-induced cardiomyopathy-An update. Eur J Pharmacol. 2018;818:241-53.

11. Wood SC, Tang X, Tesfamariam B. Paclitaxel potentiates inflammatory cytokine-induced prothrombotic molecules in endothelial cells. J Cardiovasc Pharmacol. 2010;55:276-85.

12. Herrmann J, Yang EH, Iliescu CA, Cilingiroglu M, Charitakis K, Hakeem A, et al. Vascular toxicities of cancer therapies: the old and the new - an evolving avenue. Circulation. 2016; 133:1272-89.

13. Ben Aharon I, Bar Joseph H, Tzabari M, Shenkman B, Farzam N, Levi M, et al. Doxorubicin-induced vascular toxicity - targeting potential pathways may reduce procoagulant activity. PLoS ONE. 2013;20:8.

14. Jordan MA, Wilson L. Microtubules as a target for anticancer drugs. Nat Rev Cancer. 2004;4:253-65.

15. Rowinsky EK, McGuire WP, Guarnieri T, Fisherman JS, Christian MC, Donehower RC. Cardiac disturbances during the administration of taxol. J Clin Oncol. 1991;9:1704-12.

16. Yoh K, Niho S, Goto K, Ohmatsu H, Kubota K, Kakinuma R, et al. Randomized trial of drip infusion versus bolus injection of vinorelbine for the control of local venous toxicity. Lung Cancer. 2007;55:337-41.

17. Yamada T, Egashira N, Imuta M, Yano T, Yamauchi Y, Watanabe $\mathrm{H}$, et al. Role of oxidative stress in vinorelbine-induced vascular endothelial cell injury. Free Radic Biol Med. 2010;48:120-7.

18. Polk A, Vaage-Nilsen M, Vistisen K, Nielsen DL. Cardiotoxicity in cancer patients treated with 5-fluorouracil or capecitabine: a systematic review of incidence, manifestations and predisposing factors. Cancer Treat Rev. 2013;39:974-84.

19. Kosmas C, Kallistratos MS, Kopterides P, Syrios J, Skopelitis H, Mylonakis N, et al. Cardiotoxicity of fluoropyrimidines in different schedules of administration: a prospective study. J Cancer Res Clin Oncol. 2008;134:75-82.
20. Polk A, Vistisen K, Vaage-Nilsen M, Nielsen DL. A systematic review of the pathophysiology of 5-fluorouracil-induced cardiotoxicity. BMC Pharmacol Toxicol. 2014;4:15-47.

21. Dasanu CA. Gemcitabine: vascular toxicity and prothrombotic potential. Expert Opin Drug Saf. 2008;7:703-16.

22. Qasem A, Abdulhak AAB, Aly A, Moormeier J. Capecitabineinduced Takotsubo cardiomyopathy: a case report and literature review. Am J Ther. 2014;23:1188-92.

23. Howard SC, McCormick J, Pui C-H, Buddington RK, Harvey RD. Preventing and managing toxicities of high-dose methotrexate. Oncologist. 2016;12:1-12.

24. Hansel TT, Kropshofer H, Singer T, Mitchell JA, George AJT. The safety and side effects of monoclonal antibodies. Nat Rev Drug Discov. 2010;9:325-38.

25. Baldo BA. Adverse events to monoclonal antibodies used for cancer therapy focus on hypersensitivity responses. Oncoimmunology. 2013;10:2.

26. Kamba T, McDonald DM. Mechanisms of adverse effects of antiVEGF therapy for cancer. Br J Cancer. 2007;96:1788-95.

27. Choueiri TK, Schutz FAB, Je Y, Rosenberg JE, Bellmunt J. Risk of arterial thromboembolic events with sunitinib and sorafenib: a systematic review and meta-analysis of clinical trials. J Clin Oncol. 2010;28:2280-5.

28. Qi WX, Shen Z, Tang LN, Yao Y. Bevacizumab increases the risk of gastrointestinal perforation in cancer patients: a meta-analysis with a focus on different subgroups. Eur J Clin Pharmacol. 2014;70:893-906

29. Moslehi JJ, Deininger M. Tyrosine kinase inhibitor-associated cardiovascular toxicity in chronic myeloid leukemia. J Clin Oncol. 2015;10:4210-8.

30. Amir E, Seruga B, Niraula S, Carlsson L, Ocaña A. Toxicity of adjuvant endocrine therapy in postmenopausal breast cancer patients: a systematic review and meta-analysis. J Natl Cancer Inst. 2011;103:1299-309.

31. Burstein HJ, Prestrud AA, Seidenfeld J, Anderson H, Buchholz TA, Davidson NE, et al. American Society of Clinical Oncology clinical practice guideline: update on adjuvant endocrine therapy for women with hormone receptor-positive breast cancer. J Clin Oncol. 2010;4:3784-96.

32. Abdel-Qadir H, Amir E, Fischer HD, Fu L, Austin PC, Harvey PJ, et al. The risk of myocardial infarction with aromatase inhibitors relative to tamoxifen in post-menopausal women with early stage breast cancer. Eur J Cancer. 2016;68:11-21.

33. Varricchi G, Marone G, Mercurio V, Bonaduce D, Tocchetti CG. Immune checkpoint inhibitors and cardiac toxicity: an emerging issue. Curr Med Chem. 2017;25(11):1327-39.

34. Darvin P, Toor SM, Sasidharan Nair V, Elkord E. Immune checkpoint inhibitors: recent progress and potential biomarkers. Exp Mol Med. 2018;15:50.

35. Palumbo A, Rajkumar SV, Dimopoulos MA, Richardson PG, San Miguel J, Barlogie B, et al. Prevention of thalidomide- and lenalidomide-associated thrombosis in myeloma. Leukemia. 2008;22:414-23.

36. McGrath SE, Webb A, Walker-Bone K. Bleomycin-induced Raynaud's phenomenon after single-dose exposure: risk factors and treatment with intravenous iloprost infusion. J Clin Oncol. 2013;31(4):e51-2.

37. Grünwald V, Bolte O, Wiebe S, Ganser A, Schöffski P. Acral necrosis after inadequate excessive administration of bleomycin in a testicular cancer patient. Onkologie. 2005;28(1):41-3.

38. Zamorano JL, Lancellotti P, Rodriguez Muñoz D, Aboyans V, Asteggiano R, Galderisi M, et al. 2016 ESC Position Paper on cancer treatments and cardiovascular toxicity developed under the auspices of the ESC Committee for Practice Guidelines. Eur Heart J. 2016;74:2768-801. 
39. Lyman GH, Khorana AA, Kuderer NM, Lee AY, Arcelus JI, Balaban EP, et al. Venous thromboembolism prophylaxis and treatment in patients with cancer: American Society of Clinical Oncology clinical practice guideline update. J Clin Oncol. 2013;31:2189-204.

40. Virani SA, Dent S, Brezden-Masley C, Clarke B, Davis MK, Jassal DS, et al. Canadian Cardiovascular Society guidelines for evaluation and management of cardiovascular complications of cancer therapy. Can J Cardiol. 2016;32:831-41.

41. Khorana AA, Kuderer NM, Culakova E, Lyman GH, Francis CW. Development and validation of a predictive model for chemotherapy-associated thrombosis. Blood. 2008;111:4902-7.

42. Lubberts S, Boer H, Altena R, Meijer C, Van Roon AM, Zwart N, et al. Vascular fingerprint and vascular damage markers associated with vascular events in testicular cancer patients during and after chemotherapy. Eur J Cancer. 2016;63:180-8.

43. Gizzi M, Oberic L, Massard C, Poterie A, Gwenael LT, Loriot Y, et al. Predicting and preventing thromboembolic events in patients receiving cisplatin-based chemotherapy for germ cell tumours. Eur J Cancer. 2016;69:151-7.

44. Verso M, Agnelli G, Barni S, Gasparini G, LaBianca R. A modified Khorana risk assessment score for venous thromboembolism in cancer patients receiving chemotherapy: the Protecht score. Intern Emerg Med. 2012;7(3):291-2.

45. Fung C, Fossa SD, Milano MT, Sahasrabudhe DM, Peterson DR, Travis LB. Cardiovascular disease mortality after chemotherapy or surgery for testicular nonseminoma: a population-based study. J Clin Oncol. 2015;33:3106-14.

46. Nuver J, Smit AJ, Van Der Meer J, Van Den Berg MP, Van Der Graaf WTA, Meinardi MT, et al. Acute chemotherapy-induced cardiovascular changes in patients with testicular cancer. J Clin Oncol. 2005;23:9130-7.

47. Barni S, Labianca R, Agnelli G, Bonizzoni E, Verso M, Mandalà $\mathrm{M}$, et al. Chemotherapy-associated thromboembolic risk in cancer outpatients and effect of nadroparin thromboprophylaxis: results of a retrospective analysis of the PROTECHT study. J Transl Med. 2011;9(1):79.

48. Brouha ME, Bloemendal HJ, Kappelle LJ, Winter JB. Cerebral infarction and myocardial infarction due to cisplatin-containing chemotherapy. Ned Tijdschr Geneeskd. 2003;147:457-60.

49. Dieckmann KP, Gehrckens R. Thrombosis of abdominal aorta during cisplatin-based chemotherapy of testicular seminoma-a case report. BMC Cancer. 2009;9:459.

50. Yusuf SW, Sami S, Daher IN. Radiation-induced heart disease: a clinical update. Cardiol Res Pract. 2011;2011:1-9.

Publisher's Note Springer Nature remains neutral with regard to jurisdictional claims in published maps and institutional affiliations. 